\title{
Immobilized laccase mediated dye decolorization and transformation pathway of azo dye acid red 27
}

\author{
Meenu Chhabra", Saroj Mishra² and Trichur Ramaswamy Sreekrishnan²
}

\begin{abstract}
Background: Laccases have good potential as bioremediating agents and can be used continuously in the immobilized form like many other enzymes.

Methods: In the present study, laccase from Cyathus bulleri was immobilized by entrapment in Poly Vinyl Alcohol (PVA) beads cross-linked with either nitrate or boric acid. Immobilized laccase was used for dye decolorization in both batch and continuous mode employing a packed bed column. The products of degradation of dye Acid Red 27 were identified by LC MS/MS analysis.

Results: The method led to very effective (90\%) laccase immobilization and also imparted significant stability to the enzyme (more than $70 \%$ after 5 months of storage at $4^{\circ} \mathrm{C}$ ). In batch decolorization, $90-95 \%$ decolorization was achieved of the simulated dye effluent for up to 10-20 cycles. Continuous decolorization in a packed bed bioreactor led to nearly $90 \%$ decolorization for up to 5 days. The immobilized laccase was also effective in decolorization and degradation of Acid Red 27 in the presence of a mediator. Four products of degradation were identified by LC-MS/MS analysis.
\end{abstract}

Conclusions: The immobilized laccase in PVA-nitrate was concluded to be an effective agent in treatment of textile dye effluents.

Keywords: Immobilization, Polyvinylalcohol beads, Laccase-mediator, Acid Red 27, Azo dye degradation

\section{Introduction}

The effluents generated from textile industries are reported to be one of the top ten contaminating sources of water bodies. Ligninolytic enzymes, including laccases, produced by white rot fungi find immense applications in treatment of the toxic wastes generated from textile industries [1,2]. Application of laccases for dye degradation has not been reported so far on an industrial scale mainly because of the high cost of production of these enzymes. In any treatment method, development of a reusable enzyme system, such as that generated by immobilization of enzymes, is most beneficial.

Several attempts have been made to immobilize laccases $[3,4]$. A number of studies report on the use of immobilized laccase preparations for dye decolorization [4-12]. Immobilization of laccase has been reported to

\footnotetext{
* Correspondence: meenuchhabra@iitj.ac.in

'Department of Biology, Indian Institute of Technology-Jodhpur, Jodhpur 342011, Rajasthan, India

Full list of author information is available at the end of the article
}

increase thermostability and resistance to inhibitors when compared to the free enzyme $[6,7,12]$. While most of these studies report the use of immobilized preparations in the batch mode, Palmieri et al. [13] used laccase, immobilized in copper alginate beads, to perform continuous decolorization of dye solutions. However, an additional step that involved coating immobilized enzyme beads with chitosan was added to prevent leaching of laccase during decolorization [13]. Keeping in view the benefits of continuous decolorization and to circumvent additional steps required to reduce laccase leaching, the aim of this study was to immobilize Cyathus bulleri laccase. Laccase from this fungus has been demonstrated to decolorize a number of reactive dyes $[14,15]$. The rates of dye decolorization were significantly enhanced in the presence of mediators [16,17]. This laccase was immobilized in Poly Vinyl Alcohol (PVA) based polymers crosslinked either by nitrate or boric acid. PVA is a reasonably cheap material and its polymers are reported to have high mechanical strength [18]. The 
PVA immobilized laccase preparation was tested for its applicability in batch and continuous decolorization processes. Immobilized laccase was also used to investigate degradation of an azo dye, namely, Acid Red (AR) 27. AR 27, also known as Amaranth, is an anionic azo dye and is applied to natural and synthetic fibers, paper, leather, and phenol-formaldehyde resins. It was more commonly used as food and cosmetic colorant. However, its use has been banned in USA by food and drug administration (FDA) as it is a suspected carcinogen. The dye is known to be decolorized by treatment with laccase/laccase-mediators [10] but no work has been done to elucidate its breakdown by laccase.

The present study was thus conducted with the following major objectives: (i) to immobilize laccase in PVA based beads and to test its stability and efficacy for both batch and continuous decolorization and (ii) to determine degradation capability of the immobilized laccase + mediator on AR 27 and to characterize the degradation products

\section{Materials and methods Laccase production}

Laccase was produced in the culture supernatant of $C$. bulleri by cultivating it in basal liquid medium as described previously [14]. The culture filtrate was concentrated by ultrafiltration using $10 \mathrm{kDa}$ membrane in a stirred cell (Amicon). The specific activity of laccase was $31 \mathrm{U} / \mathrm{mg}$ protein using guaiacol as a substrate.

\section{Laccase immobilization}

Laccase was entrapped in beads by two different methods. The materials and gel matrices (sodium alginate, calcium chloride, PVA, boric acid and sodium nitrate) were obtained from Himedia labs and Merck chemicals. The concentrated culture filtrate was mixed thoroughly with PVA-alginate solution. The final concentration of PVA and alginate was $8 \%$ and $1 \%$ respectively. This solution was centrifuged at $4000 \mathrm{rpm}$ for $5 \mathrm{~min}$ to remove air bubbles and filled in a $10 \mathrm{ml}$ syringe. Beads were prepared by extruding the mixture as drops into a stirred saturated boric acid solution to form beads and these were allowed to stay in the same solution for $20 \mathrm{~min}$. The beads were then transferred to $1 \mathrm{M}$ sodium dihydrogen phosphate solution for hardening and further incubated for $1 \mathrm{~h}$. The hardened beads were then

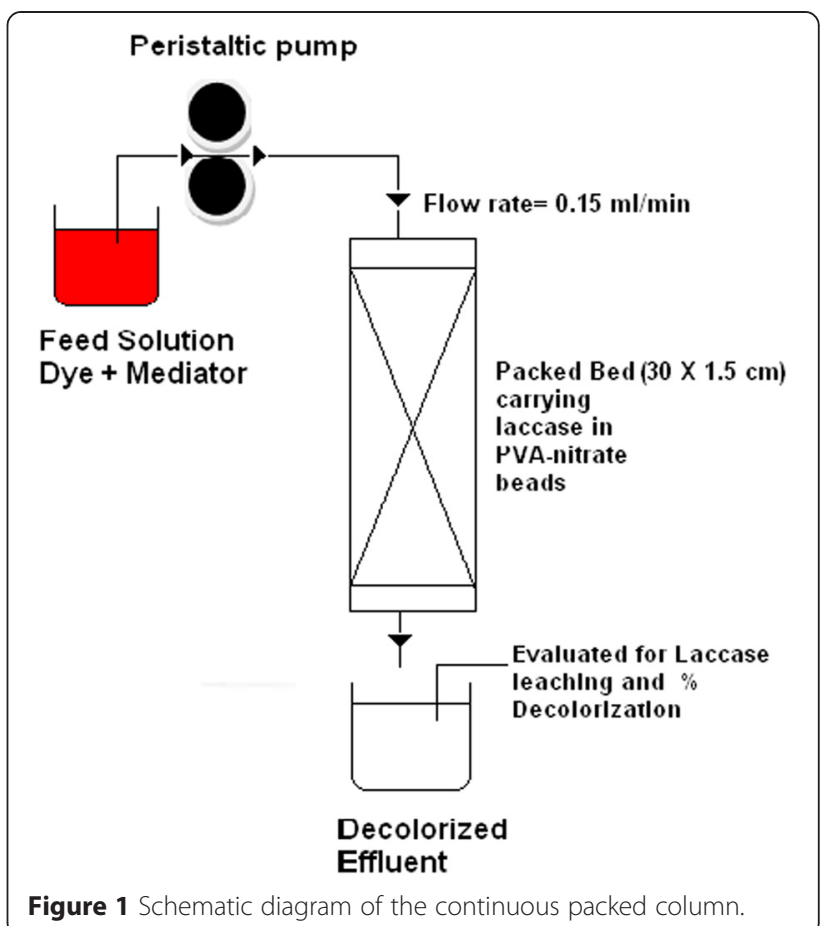

extensively washed with distilled water and stored in a minimum amount of water at $4^{\circ} \mathrm{C}$. PVA-nitrate beads were prepared by extruding the PVA-alginate-enzyme mixture as drops into stirred $50 \%(\mathrm{w} / \mathrm{v})$ solution of sodium nitrate containing $1 \%$ calcium chloride $(\mathrm{w} / \mathrm{v})$. The beads were allowed to stand in this solution for $6 \mathrm{~h}$ after which washings with distilled water were performed. The resultant beads were stored in minimum amount of water at $4^{\circ} \mathrm{C}$.

The washings were collected to determine laccase activity. Percent immobilization was calculated by subtracting the activity lost in washings from the number of initially loaded units used for immobilization. In order to determine the specific activity, i.e. number of active laccase units/g of beads, the laccase assay was performed at $55^{\circ} \mathrm{C}$ which resulted in bead dissolution. Total protein was estimated by Lowry's method.

\section{Determination of laccase leaching and bead stability}

Leaching of laccase from beads was determined by incubating specific number of beads with a fixed initial activity in $5 \mathrm{ml}$ of $50 \mathrm{mM}$ sodium acetate buffer, $\mathrm{pH}$ 5.0. The

Table 1 Laccase immobilization and residual laccase activity in immobilized preparations

\begin{tabular}{lllll}
\hline Entrapment method & \% immobilization & $\begin{array}{l}\text { \% Laccase activity retained after } \mathbf{1 0 8} \mathbf{h} \\
\text { incubation at } \mathbf{1 0 0} \mathbf{~ r p m}, \mathbf{p H ~} \mathbf{5 . 5} \text { at } \mathbf{3 0} \mathbf{C} .\end{array}$ & $\begin{array}{l}\text { \% Intact beads } \\
\text { at } \mathbf{1 0 0 0} \mathbf{~ r p m}\end{array}$ & $\begin{array}{l}\text { \% Laccase activity retained after } \\
\text { incubating at } \mathbf{1 0 0 0} \mathbf{~ r p m}\end{array}$ \\
\hline PVA-boric acid & $65 \pm 5$ & $43 \pm 2$ & $92 \pm 3$ & 0 \\
PVA-nitrate & $90 \pm 2$ & $73 \pm 2$ & $100 \pm 0$ & $20 \pm 1$ \\
\hline
\end{tabular}


Table 2 Comparison of properties of immobilized and free laccase

\begin{tabular}{lll}
\hline Parameter & $\begin{array}{l}\text { PVA-nitrate immobilized } \\
\text { laccase }\end{array}$ & Free laccase \\
\hline IC 50 for chloride & $450 \pm 22 \mathrm{mM}$ & $600 \pm 33 \mathrm{mM}$ \\
IC 50 for EDTA & $250 \pm 17 \mathrm{mM}$ & $250 \pm 10 \mathrm{mM}$ \\
IC 50 for sodium azide & $6 \pm 0.3 \mu \mathrm{M}$ & $5 \pm 0.5 \mu \mathrm{M}$ \\
$\mathrm{K}_{\mathrm{m}}$ (ABTS) & $65 \pm 4 \mu \mathrm{M}$ & $37 \pm 2.1 \mu \mathrm{M}$ \\
$\mathrm{K}_{\text {cat }}$ (ABTS) & $1675 \pm 75 \mathrm{sec}^{-1}$ & $2996 \pm 179 \mathrm{sec}^{-1}$ \\
\hline
\end{tabular}

beads were shaken at $100 \mathrm{rpm}$ at $30^{\circ} \mathrm{C}$. Enzyme activity was measured in the samples withdrawn after specific time intervals. The final activity was subtracted from the initial activity to determine enzyme loss due to leaching.

Bead stability was determined by incubating 10 intact beads in $2 \mathrm{ml}$ of distilled water in a $25 \mathrm{ml}$ conical flask and stirring at different speeds (ranging from $50-1000 \mathrm{rpm}$ ) for $30 \mathrm{~min}$ (modified protocol Yujian et al. [19]). The \% intact granules $\mathrm{v} / \mathrm{s} \mathrm{rpm}$ plot was obtained for two different kinds of beads. The amount of laccase activity retained by immobilized preparations was determined.

\section{Characterization of immobilized laccase}

Laccase stability, optimum $\mathrm{pH}$, temperature, resistance to some laccase inhibitors (chloride ions, sodium azide and EDTA after $1 \mathrm{~h}$ pre-incubation) and kinetic parameters $\left(\mathrm{K}_{\mathrm{m}}\right.$ and $\left.\mathrm{K}_{\mathrm{cat}}\right)$ were determined and compared to that of the free enzyme. Laccase assays were performed using either guaiacol or 2,2'-azino-bis (3-ethylbenzothiazoline6-sulphonic acid) or ABTS as a substrate as described earlier [14] by adding fixed amount of either free or immobilized laccase. The concentration range of laccase inhibitors used for IC50 calculation ranged from 0-2000 mM NaCl, 0-1000 mM EDTA and 0-50 $\mu \mathrm{M}$ sodium azide. The ABTS concentration range for calculating $\mathrm{K}_{\mathrm{m}}$ and $\mathrm{K}_{\text {cat }}$ values was $0-1 \mathrm{mM}$. The values of catalytic constants were measured using the Lineweaver Burk plot. The value of $\mathrm{K}_{\mathrm{cat}}$ was determined by dividing $V_{\max }$ with total enzyme cocentration $\left[\mathrm{E}_{\text {tot }}\right]$.

\section{Decolorization experiment using immobilized enzyme}

Decolorization experiments were performed using the conditions optimized previously [17]. Decolorization re-
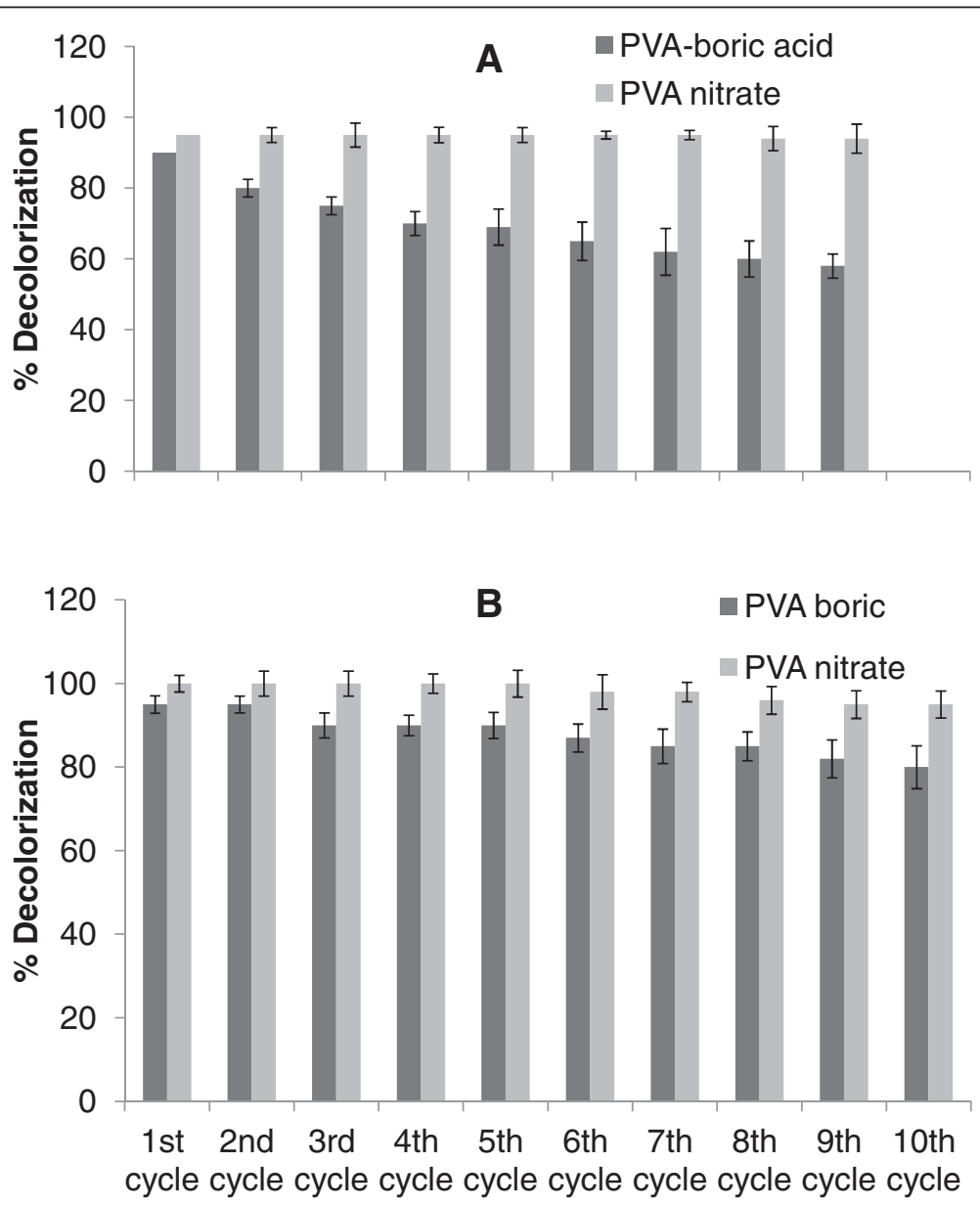

Figure 2 Batch decolorization of simulated effluent using PVA-boric acid and PVA-nitrate entrapped laccase. (A) Acid violet 17 or (B) Basic Green 4. 
action was performed in a $25 \mathrm{ml}$ conical flask. The reaction mixture consisted of either $100 \mu \mathrm{M}$ of Acid Violet 17 or Basic Green 4 solution (that simulated absorbance of the textile effluent), $100 \mu \mathrm{M}$ of ABTS and immobilized enzyme $(100 \mathrm{mU} / \mathrm{ml})$. The incubation was done at $30^{\circ} \mathrm{C}$ at $100 \mathrm{rpm}$. The change in absorbance at $542 \mathrm{~nm}$ $\left(\lambda_{\max }\right.$ of Acid Violet 17) and $618 \mathrm{~nm}\left(\lambda_{\max }\right.$ of Basic Green 4) was used to compute \% decolorization. After one cycle of decolorization ( $90 \%$ decolorization), liquid was withdrawn and fresh dye solution was added to initiate a new cycle of decolorization.

\section{Continuous decolorization in a packed bed column}

Continuous decolorization of the simulated effluent was carried out in a column $(30 \mathrm{~cm} \times 1.5 \mathrm{~cm})$ with approximate working volume of $50 \mathrm{ml}$. The schematic diagram of the same is shown in Figure 1. The simulated effluent contained $100 \mu \mathrm{M}$ Acid Violet 17, as used in the local textile mills $(\mathrm{m} / \mathrm{z} 710$ and also with some unidentified peaks), $2.5 \mathrm{~g} \mathrm{l}^{-1}$ sodium sulfate as per the specifications for dyeing wool, and $100 \mu \mathrm{M}$ ABTS in $50 \mathrm{mM}$ sodium acetate buffer ( $\mathrm{pH}$ 5.5). This feed solution was saturated with oxygen and continuously fed into the column using a peristaltic pump at a flow rate of $0.15 \mathrm{ml} / \mathrm{min}$. This flow rate was selected through initial optimization experiments based on determining an effective hydraulic retention time for decolorization of the dye. The bed was earlier saturated with the dye solution without mediator in order to rule out decolorization due to adsorption on the matrix. Percent decolorization was determined at different time intervals. The samples were also assayed for leached laccase activity.

Degradation of AR 27 (obtained from Sigma Aldrich) was performed using $100 \mu \mathrm{M}$ AR $27+1 \mathrm{mM} 1$ hydroxybenzotriazole monohydrate (HOBT). The concentration of mediator was selected based on the previous reports [5]. The decolorization reaction was monitored at $515 \mathrm{~nm}$.

\section{Toxicity and mutagenicity assessment}

Toxicity analysis was done by measuring decline in oxygen consumption rate of Pseudomonas putida. Mutagenicity was assessed by standard Ames test using Salmonella typhimurium TA 98 and 100 strains as described earlier [16].

\section{Mass analysis}

LC-MS analysis was performed for analysis of degradation products of AR 27 using Perkin Elmer HPLC coupled with Qstar Electrospray ionization (ESI) high resolution mass spectrometer (Applied Biosystems, USA) equipped with quadruple and Time of Flight mass analyzers. The decolorized dye samples were introduced into the reverse phase C-18 HPLC column (LiChrospher) using an autosampler at a flow rate of
$0.2 \mathrm{ml} / \mathrm{min}$. Elution was performed using a combination of solvent $\mathrm{A}$ (acetonitrile) and solvent $\mathrm{B}$ (water) in 1:1 ratio. The products were monitored at $210 \mathrm{~nm}$ using a UV-Visible detector. The flow coming from HPLC was introduced into the mass spectrometer (MS). The MS was operated in the negative ion mode and other parameters were set as follows: ion spray voltage $-4500 \mathrm{~V}$, Nebulizer gas: $35 \mathrm{lb} / \mathrm{in}^{2}$, Curtain gas: $25 \mathrm{lb} / \mathrm{in}^{2}$, Declustering potential: $-80 \mathrm{~V}$, Focussing potential: $265 \mathrm{~V}$. Collision energy was varied from -20 to $-80 \mathrm{~V}$ for analyzing product ion spectra.

\section{Results and discussion}

Laccase immobilization, leaching and bead stability

PVA-boric acid and PVA-nitrate gave 65 and 90\% immobilization respectively. Leaching of laccase was monitored in both preparations and it was found that PVA-nitrate retained 75\% laccase activity after $108 \mathrm{~h}$ of incubation at $30^{\circ} \mathrm{C}$ at $100 \mathrm{rpm}$ (Table 1). Both the bead type were highly stable even up to $1000 \mathrm{rpm}$. While PVA-boric acid beads exhibited rapid loss in laccase activity, PVA-nitrate beads retained 20\% laccase activity even after incubation at $1000 \mathrm{rpm}$ (Table 1).

The major obstacles in implementing laccase-mediator systems for bioremediation at an industrial scale are the cost of the enzyme and the mediators. Immobilized enzymes allow for an efficient use of available catalyst. Multiple batches of substrates can be processed as the enzyme does not get washed off with the effluent [20].

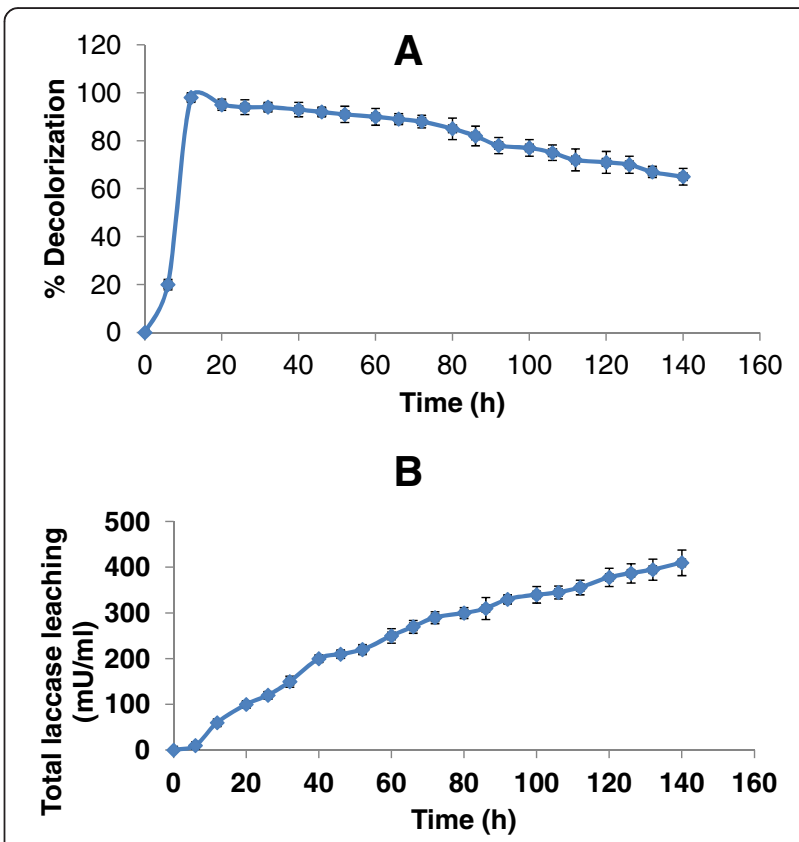

Figure $\mathbf{3}$ Continuous decolorization in packed bed column using PVA-nitrate beads. (A) Profile of dye decolorization with time and (B) Leaching of laccase from the column. 
Table 3 Summary of the degradation products of Acid Red 27 after laccase-mediator action as observed by ESI-MS/MS

\begin{tabular}{|c|c|c|c|}
\hline Product & Mass/charge $(\mathrm{m} / \mathrm{z})$ & $\begin{array}{l}\text { Major product ion peaks as observed } \\
\text { in MS/MS spectrum }\end{array}$ & \\
\hline & & Collision Energy (V) & $\mathrm{m} / \mathrm{z}$ (\% Relative intensities) \\
\hline Dye alone & {$[\mathrm{M}-\mathrm{H}]-=536.97$} & -50 & $\begin{array}{l}316.97 \text { (100); } 301.96(50) ; 237.02(40) 206.00(30) ; 79.96(30) ; \\
518.96 \text { (20); } 457.02 \text { (10); } 439.00 \text { (10); } 377.07 \text { (5) } 365.09(5) \text {. }\end{array}$ \\
\hline । & {$[\mathrm{M}-\mathrm{H}]-=535.9$} & -50 & $\begin{array}{l}315.97(100) ; 301.96(50) ; 236.02(40) 206.00(30) ; 79.96(30) ; \\
518.96(20) ; 457.02(10) ; 439.00(10) ; 377.07(5) 365.09(5)\end{array}$ \\
\hline$\|$ & {$[\mathrm{M}-\mathrm{H}]-=235.01$} & -30 & 182.65 (100); 233.99 (45); 79.95 (30); 219.99 (20). \\
\hline III & {$[\mathrm{M}-\mathrm{H}]-=207.01$} & -30 & 207.01 (100); 183.01 (50); 79.95 (40); 119.05 (20) \\
\hline IV & {$[\mathrm{M}-\mathrm{H}]-=316.94$} & -40 & $\begin{array}{l}316.9(100) ; 289(50) ; 245.06(20) ; 79.95 \text { (15); } 255.20(10) ; \\
145.0310 \text { (10); } 236.98 \text { (5). }\end{array}$ \\
\hline
\end{tabular}

Also, immobilized enzymes generally exhibit higher resistance to inhibitors and high temperatures. The process of immobilization itself should also be less expensive, easy to perform and effective and this can generally be achieved using cheaper matrices and easy methods of immobilization. Any method which fulfills the above criteria qualifies to be used at large scale making the overall process economical.

The suitability of any immobilized enzyme preparation is largely dependent on the mechanical and chemical stability of the immobilization matrix. In earlier work, immobilization of laccase was carried out in alginate beads cross linked with calcium, copper or zinc. Copper alginate and zinc alginate showed high \% immobilization and laccase retention but these preparations were unstable both mechanically and chemically. In the present study, laccase was immobilized in PVA-boric acid and PVA-nitrate beads, making it the first study involving PVA for this enzyme. The immobilization was performed by modifications in the protocol given by Chang and Tseng [21]. Also, this immobilization method fulfilled most of the criteria listed above The beads were found to be stable and of high mechanical strength, a property described earlier also [22]. Also, higher percentage of laccase was immobilized. The beads were stable enough to be used in continuous operations in a column reactor. Palmeiri et al. [13] and Brandi et al. [23] reported 65\% immobilization of laccase in copper alginate beads. Lower values for immobilization also mean using higher quantities of initial enzyme making the process expensive [24]. Liu et al., [25] reported 91\% retention of laccase activity during immobilization on carbon based mesoporous magnetic composites. The preparation of such composites, however, involved complicated procedures while entrapment by far is the easiest way to immobilize enzymes.

\section{Characterization of immobilized laccase}

It was found that immobilization of laccase did not confer any increased resistance to common inhibitors such as chlorides, EDTA and azide. The IC50 values were nearly equal to that of the free enzyme. The immobilized laccase, however, displayed lower affinity $\left(\mathrm{K}_{\mathrm{m}}\right)$ for ABTS compared to the free enzyme. The $K_{\text {cat }}$ values also decreased for the immobilized enzyme (Table 2). This observation has been made with several other immobilized enzyme preparations $[4,23]$ and is attributed to mass transfer resistance displayed by enzymes in the entrapped

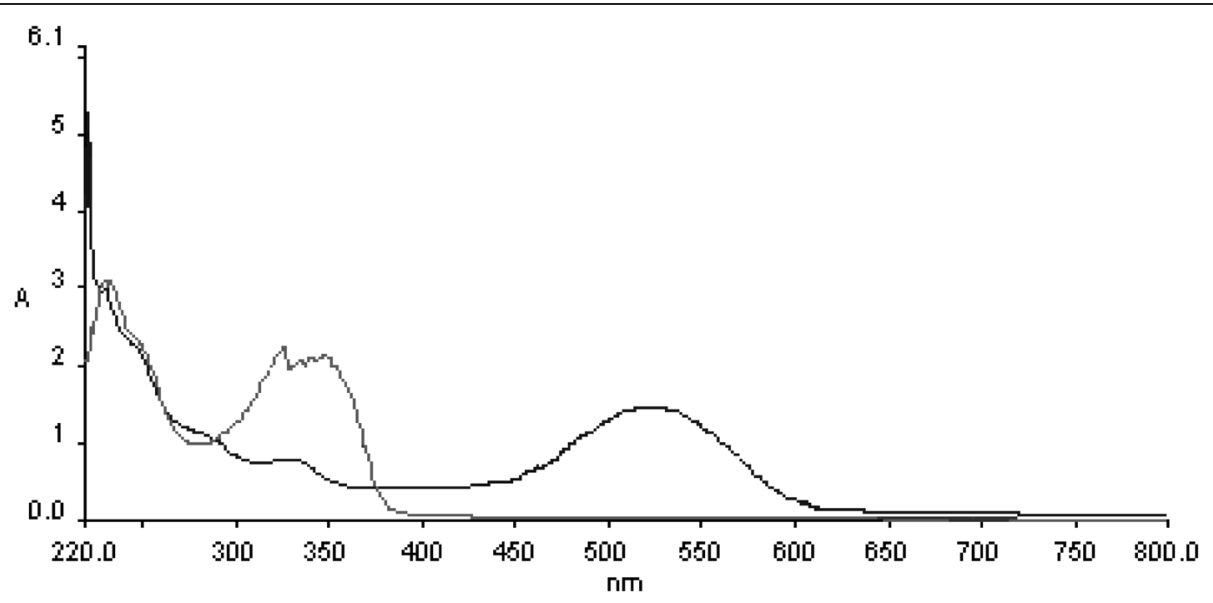

Figure 4 Absorption profile of AR 27 (-) and AR 27 treated with laccase and 1-HOBT (-). 
state. This eventually leads to a decline in catalytic efficiency. In our study, this can also be attributed to the low permeability of PVA beads leading to low diffusivity of dyes as well as oxygen required for laccase action. The storage stability of the immobilized enzyme, however, was substantially increased as compared to the free enzyme and is the highest reported till now. The only other highly stable laccase was reported by immobilization in controlled porosity silica beads [26].

The enzyme stability increased for immobilized preparations with more than $80 \%$ activity remaining after 4 months of storage at $4^{\circ} \mathrm{C}$. Free laccase, on the other hand, exhibited complete loss in activity in a period of less than a month. The optimum $\mathrm{pH}$ and temperature of the laccase remained the same with ABTS for immobilized preparations as that for the free enzyme.

\section{Batch decolorization using the immobilized laccase}

In order to determine the decolorization efficiency of the immobilized enzyme in batch mode, an acidic and a basic dye were selected. Acid Violet 17 decolorized at a much slower rate compared to Basic Green 4 [17]. Therefore, both the dyes offered different chemical structure and decolorization kinetics making them appropriate to determine the behavior of immobilized laccase. Decolorization of two different simulated effluents,<smiles></smiles>

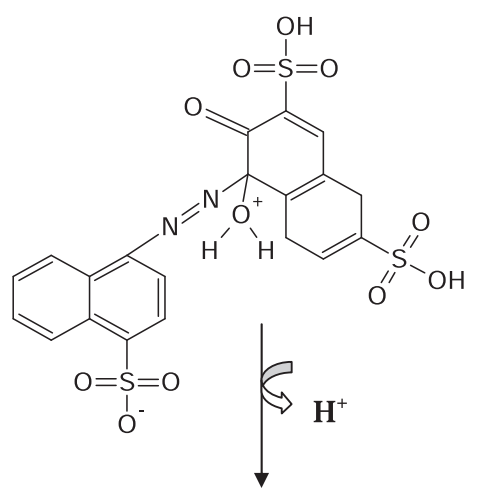

Attack by water molecule<smiles>O=C1[C](N=Nc2ccc(S(=O)(=O)O)c3ccccc23)C2=C(C=C1S(=O)(=O)O)CC(S(=O)(=O)O)=CC2</smiles><smiles>O=C1C(S(=O)(=O)O)=CC2=C(CC=C(S(=O)(=O)O)C2)C1(O)N=Nc1ccc(S(=O)(=O)O)c2ccccc12</smiles>

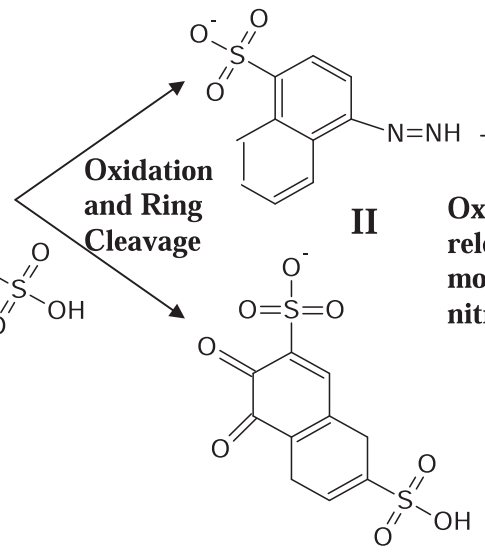

IV

Figure 5 Proposed pathway of decolorization of AR 27 using laccase-mediator system. 
one containing Acid Violet 17 and the other containing Basic Green 4 was performed. PVA-nitrate beads were chemically stable in both the dye solutions and led to 95\% decolorization of Basic Green 4 even up to 20 cycles. In batch mode, the preparations also led to $90 \%$ decolorization of the effluent containing Acid Violet 17 up to 10 cycles (Figure 2A and B). The results were promising when compared to previous reports wherein the immobilized laccase was not highly reusable in batch studies. This was largely due to loss in laccase activity due to leaching or inactivation $[13,23]$.

\section{Continuous decolorization using immobilized laccase}

The immobilized laccase preparations were used to perform decolorization of the simulated effluent. The decline in \% decolorization achieved in packed bed column was directly correlated with remaining laccase activity in the beads. PVA-nitrate packed bed retained $60 \%$ of the initial laccase activity even after $120 \mathrm{~h}$ of use. The decolorization of the simulated effluent was also more than $70 \%$ up to $120 \mathrm{~h}$ (Figure $3 \mathrm{~A}$ and B).

\section{AR 27 decolorization and degradation using immobilized laccase}

AR 27 was decolorized by laccase only in the presence of the mediator, as is characteristic of most high redox dyes. Mass spectra of the dye gave multiple peaks which were attributed to sodium and potassium adducts of the dye. Differential ionization of the dye molecule gives multiple peaks at different $\mathrm{m} / \mathrm{z}$. The analysis of the decolorized samples led to identification of four products, named from I to IV (Table 3$)$. These persistent products were Compound I: 4-((2-oxo-3, 6-disulfo-2,3-dihydronaphthalen-1yl)diazenyl)naphthalene-1-sulfonate at $\mathrm{m} / \mathrm{z} 535.9$, compound II: 4-diazenylnaphthalene-1-sulfonate at $\mathrm{m} / \mathrm{z} 235.01$, compound III: naphthalene-1-sulfonate at $\mathrm{m} / \mathrm{z} 207.0$, and compound IV: 3,4-dioxo-7-sulfo-2,3,4,4a-tetrahydronaphthalene-2-sulfonate at $\mathrm{m} / \mathrm{z} 316.94$. The UV-visible absorbance scan showed complete disappearance of peaks in the visible range (Figure 4).

Figure 5 shows the proposed decolorization pathway of AR 27 by laccase-mediator. The four degradation products which were identified are proposed to appear by the action of laccase and mediator in the following way. Compound I at m/z 535.9 resulted from the oxidation of the phenolic dye group to a quinine. This laccase-mediator assisted two electron oxidation was proposed to occur via phenoxy radical formation and is one of the important intermediates through which the dye undergoes further conversion. This is followed by a nucleophilic attack by a water molecule which creates a site for further action of laccase/mediator system. This explains the formation of other identified products. Compound I undergoes further oxidation resulting in

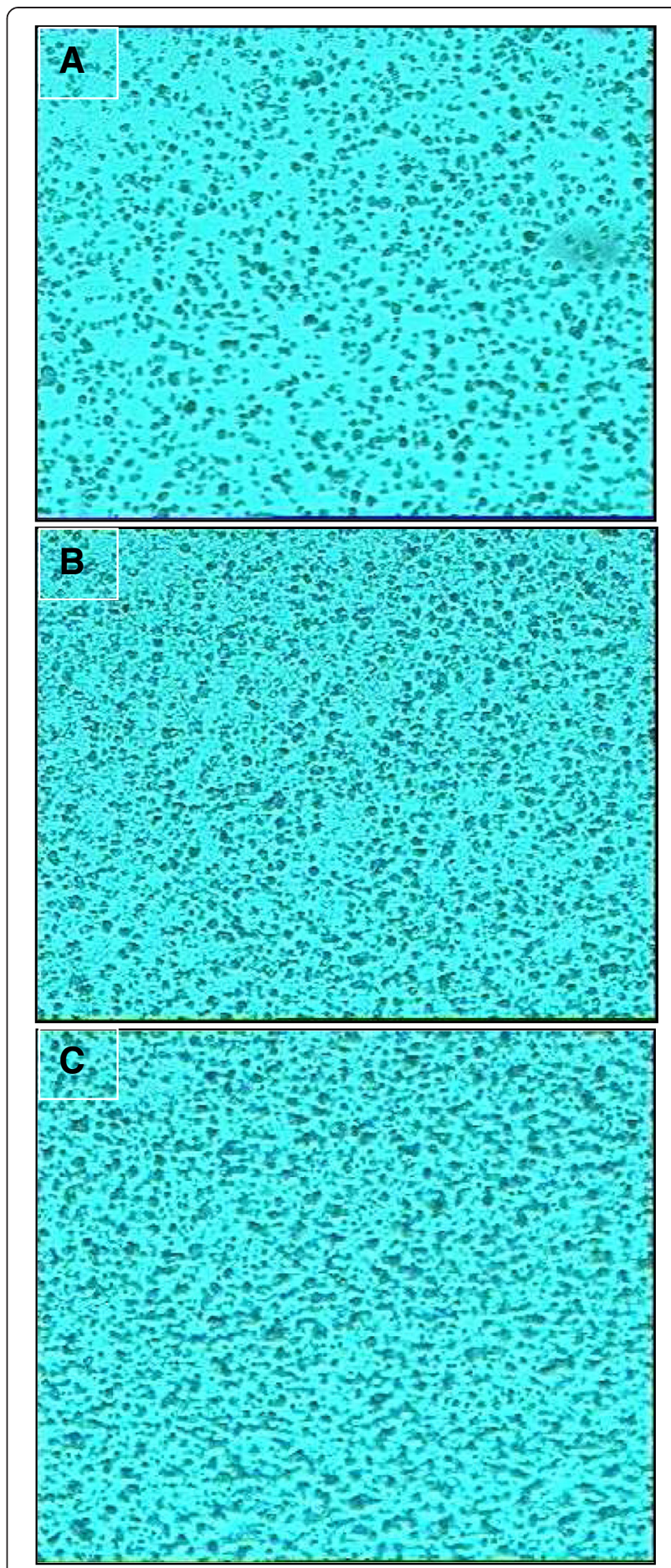

Figure 6 Background lawn of S. typhimurium TA 98 obtained during Ames test. (A) Untreated AR 27, (B) AR 27 treated with laccase and 1-HOBT, (C) Negative control-Distilled water.

splitting of the dye molecule and generation of compound II at m/z 235.01 and compound IV at m/z 316.94. Compound II gets further oxidized to compound III which was detected at $\mathrm{m} / \mathrm{z}$ 207.0. The nitrogen in the azo bond was thus released as molecular nitrogen. This 
form of azo bond disruption was earlier proposed by Chivukula and Renganathan [27]. The peak representing $\left[\mathrm{SO}_{3}\right]^{-}$at $\mathrm{m} / \mathrm{z} 79.95$ did appear in the decolorized dye spectrum. However, this was not attributed to laccase action as it also appeared in the spectrum taken with dye alone, although at slightly lower intensities. Thus, the appearance of these peaks is possibly due to ionization induced fragmentation of the dye molecule or its degradation products.

The high molecular weight polymerization products were absent which otherwise appear on treatment of dyes with free laccase on slightly long incubations. Zille et al. [28] observed high molecular weight molecules which were the polymerization products of intact dye and its degradation products obtained on longer incubations with free laccase.

\section{Toxicity and mutagenicity assessment}

AR 27 did not inhibit respiratory activity in $P$. putida but was found to be mutagenic as assessed by the Ames test. Similar observations have been made earlier [29]. Also, slight thinning of the background lawn of S. typhimurium occurred showing cytotoxic effect (Figure 6). Treatment with laccase-mediator did not add any toxicity but led to reduction in mutagenicity and also restored density of background lawns in the Ames test. This is possible as the mutagenic azo bond is disrupted by laccase-mediator action.

\section{Conclusions}

Laccase immobilized in PVA-nitrate was found to be stable for use in several decolorization studies using batch and immobilized systems. High mechanical strength of the beads allowed continuous operations in a column reactor. Immobilized laccase was also used for decolorization and degradation of the azo dye AR 27. The dye degradation studies showed that AR 27 underwent degradation to smaller moieties and a pathway of degradation was proposed. It was also concluded that polymerization products appearing during dye decolorization can be avoided through continuous decolorization process by providing just appropriate hydraulic retention time.

\section{Competing interests}

The authors declare that they have no competing interests.

\section{Authors' contributions}

MC has designed and performed the experiments and has written the manuscript. Authors SM and TRS were involved in the design of experiments and editing the manuscript. All authors read and approved the final manuscript.

\section{Acknowledgements}

Department of Biotechnology, Government of India is gratefully acknowledged for providing research grants to authors SM and TRS. Council of Scientific and Industrial Research, India is acknowledged for providing senior research fellowship to MC.

\section{Author details}

'Department of Biology, Indian Institute of Technology-Jodhpur, Jodhpur 342011, Rajasthan, India. '2Department of Biochemical Engineering and Biotechnology, Indian Institute of Technology Delhi, Hauz-Khas, New-Delhi 110016, India.

Received: 26 November 2013 Accepted: 15 April 2015

Published online: 25 April 2015

\section{References}

1. Maciel MJM, Silva ACE, Ribeiro HCT. Industrial and biotechnological applications of ligninolytic enzymes of the basidiomycota: A review. Electron J Biotechn. 2010;13:6.

2. Gholami-Borujeni F, Mahvi AH, Naseri S, Faramarzi MA, Nabizadeh R, Alimohammadi M. Enzymatic Treatment and Detoxification of Acid Orange 7 from Textile Wastewater. Appl Biochem Biotechnol. 2011;165:1274-84.

3. Durán N, Rosa MA, D'Annibale A, Gianfreda L. Applications of laccases and tyrosinases (phenoloxidases) immobilized on different supports: a review. Enzyme Microb Tech. 2002:31:907-31.

4. Fernández-Fernández M, Sanromán MA, Moldes D. Recent developments and applications of immobilized laccase. Biotechnol Adv. 2013;31:1808-25.

5. Reyes P, Pickard MA, Vazquez-Duhalt R. Hydroxybenzotriazole increases the range of textile dyes decolorized by immobilized laccase. Biotechnol Lett. 1999;21:875-80.

6. Peralta-Zamora P, Pereira CM, Tiburtius ERL, Moraes SG, Rosa MA, Minussi RC, et al. Decolorization of reactive dyes by immobilized laccase. Appl Catal B Environ. 2003:42:131-44.

7. Kunamneni A, Ghazi I, Camarero S, Ballesteros A, Plou FJ, Alcalde M. Decolorization of synthetic dyes by laccase immobilized on epoxy-activated carriers. Process Biochem. 2008:43:169-78.

8. Ping W, Xuerong F, Li C, Qiang W, Aihui Z. Decolorization of reactive dyes by laccase immobilized in alginate/gelatin blent with PEG. J Environ Sci. 2008;20:1519-22.

9. Hu X, Wang P, Hwang HM. Oxidation of Anthracene by immobilized laccase from Tramates versicolor. Bioresour Technol. 2009;100:4963-8.

10. Champagne PP, Ramsay JA. Dye decolorization and detoxification by laccase immobilized on porous glass beads. Bioresour Technol. 2010;101:2230-5.

11. Osma JF, Toca-Herrera JL, Rodriquez-Couto S. Transformation pathway of Remazol Brilliant Blue R by immobilized laccase. Bioresour Technol. 2010;101:8509-14.

12. Asgher M, Kamal S, Muhammad H, lqbal N. Improvement of Catalytic Efficiency, Thermo-stability and Dye Decolorization Capability of Pleurotus ostreatus IBL-02 laccase by Hydrophobic Sol Gel Entrapment. Chem Cent. 2012;6:110.

13. Palmieri G, Giardina P, Sannia G. Laccase-Mediated Remazol Brilliant Blue R Decolorization in a Fixed-Bed Bioreactor. Biotechnol Prog. 2005;21:1436-41.

14. Salony, Mishra S, Bisaria VS. Production and characterization of laccase from Cyathus bulleri and its use in decolorization of recalcitracnt textile dyes. Appl Microbiol Biotechnol. 2006;71:646-53.

15. Salony, Mishra S, Bisaria VS. Decolorization and detoxification of textile dyes and black liquor by laccase of Cyathus bulleri. J Sci Ind Res. 2007;66:684-8.

16. Chhabra M, Mishra S, Sreekrishnan TR. Mediator assisted decolorization and detoxification of textile dyes/ dye mixture using Cyathus bulleri laccase. Appl Biochem Biotechnol. 2008;151:587-98.

17. Chhabra M, Mishra S, Sreekrishnan TR. Laccase/mediator assisted degradation of triarylmethane dyes in a continuous membrane reactor. J Biotechnol. 2009;143(1):69-78.

18. Peijs T, Van Vught RJM, Govaert LE. Mechanical properties of poly(vinylalcohol) fibres and composites. Composites. 1995;26:83-90

19. Yujian W, Xiaojuan Y, Wei T, Hongyu L. High-rate ferrous iron oxidation by immobilized Acidithiobacillus ferrooxidans with complex of PVA and sodium alginate. J Microbiol Methods. 2006;68:212-7.

20. Gholami-Borujeni F, Mahvi AH, Naseri S, Faramarzi MA, Nabizadeh R, Alimohammadi M. Application of immobilized horseradish peroxidase for removal and detoxification of azo dye from aqueous solution. Res J Chem Environ. 2011;15(2):217-22.

21. Chen KC, Lin YF. Immobilization of microorganisms or enzymes in polyvinyl alcohol beads. US patent. 1994;5:290-693.

22. Chang CC, Tseng SK. Immobilization of Alcaligenes eutrophus using PVA crosslinked with sodium nitrate. Biotechnol Tech. 1998;12:865-8. 
23. Brandi P, D'Annibale A, Galli C, Gentili P, Pontes ASN. In search for practical advantages from the immobilisation of an enzyme: the case of laccase. J Mol Catal B: Enzym. 2006;41:61-9.

24. Ahn MY, Dec J, Kim JE, Bollag JM. Treatment of 2,4-Dichlorophenol Polluted Soil with Free and Immobilized Laccase. J Environ Qual. 2002;31:1509-15.

25. Liu Y, Zeng Z, Zeng G, Tang L, Pang Y, Li Z, et al. Immobilization of laccase on magnetic bimodal mesoporous carbon and the application in the removal of phenolic compounds. Bioresour Technol. 2012;115:21-6.

26. Champagne PP, Ramsay JA. Reactive Blue 19 decolourization by laccase on silica beads. Appl Microbiol Biotechnol. 2007;77:819-23.

27. Chivukula M, Renganathan V. Phenolic Azo Dye Oxidation by Laccase from Pyricularia oryzae. Appl Environ Microbiol. 1995;61:4374-7.

28. Zille A, Gornacka B, Rehorek A, Cavaco-Paulo A. Degradation of Azo Dyes by Trametes villosa Laccase over Long Periods of Oxidative Conditions. Appl Environ Microbiol. 2005;71:6711-8.

29. Hong Y, Guo J, Xu Z, Mo C, Xu M, Sun G. Reduction and partial degradation mechanisms of naphthylaminesulfonic azo dye amaranth by Shewanella decolorationis S12. Appl Microbiol Biotechnol. 2007;75:647-54.

\section{Submit your next manuscript to BioMed Central and take full advantage of:}

- Convenient online submission

- Thorough peer review

- No space constraints or color figure charges

- Immediate publication on acceptance

- Inclusion in PubMed, CAS, Scopus and Google Scholar

- Research which is freely available for redistribution 